\title{
GROWING SEASON THERMAL CLIMATE RECONSTRUCTED AT SIX PINE STANDS IN NORTHERN LAPLAND
}

\author{
MARKUS LINDHOLM and JOUKO MERILÄINEN
}

LINDHOLM, MARKUS and MERILÄINEN, JOUKO 1994. Growing season thermal climate reconstructed at six pine stands in northern Lapland. Bull. Geol. Soc. Finland 66, Part 2, 95-106.

At the northern coniferous timberline of the boreal region, growing season temperature is generally the major environmental factor limiting the growth processes of Scots pine (Pinus sylvestris L.). Variations in annual ring-widths of pines can be related to summer temperature parameters. Models of growth response are used to determine how these trees respond to known climatic conditions. Reconstructions of past summer temperatures are achieved by means of transfer function analysis.

The annual increments of tree-rings during their life-span were studied in an area where waether data from meteorological stations could be obtained. Eight areal chronologies were constructed and weather stations at Karesuando, Sweden, and Karasjok, Norway, provided temperature and precipitation records for comparison with the tree-ring time-series. On the basis of response function analysis July temperatures were reconstructed year by year for six areas using tree-rings of pines. A multiple regression model was produced to estimate climate in year $\mathrm{t}$ as a function of tree growth in years $t$ and $t+1$.

Key words: paleoclimatology, paleotemperature, reconstruction, tree rings, Pinus, Holocene, Enontekiö, Utsjoki, Finland.

Markus Lindholm and Jouko Meriläinen: University of Joensuu, Saima Centre for Environmental Sciences, Linnankatu 11,FIN-57130 Savonlinna, Finland. 


\section{INTRODUCTION}

The performance of a plant at a moment is determined by the state of the plant and the prevailing environmental factors. At the northern timberline of the boreal region the growth period of woody plants is limited to the polar summer, which permits synthetic activity for several weeks, without interruption at night. The chief factor affecting the increase in thickness of the annual rings of pines under the extreme conditions is thermoclimate (Aniol \& Eckstein, 1984; Briffa et al., 1988; 1990; 1992). The duration, intensity and variability of temperature limits the vital processes which control growth.

Solar radiation synchronizes development and the rhythmic events in the life cycle of trees with the seasons of the year. In pines of the boreal region just one growth ring is normally formed annually. Precise measurements of the annual increase in thickness of the stem and other properties of the yearly increments can be studied by means of tree-ring analysis (Fritts, 1976).

The goal of dendroclimatology is the reconstruction of past climatic conditions. In this study the functional relationships between the ring-widths series of Scots pine (Pinus sylvestris L.) and climatic parameters were modeled using technique described originally by Fritts (1976). The present state of dendroclimatological methods are summarized in Hughes et al. (1982) and in Cook and Kairiukstis (1989).

Radial growth patterns of pines are used to determine how these trees respond to known climatic conditions, like mean monthly temperatures and precipitation data. After defining an optimum season for reconstruction, the ring-width indices are regressed on climatic parameters and the coefficients of the equation are then applied to reconstruct past summer temperatures.

\section{STUDY AREA AND MATERIAL}

In the boreal region of Fennoscandia, the close dependence of pine growth on growing season temperatures is to be found only close to the polar/ alpine tree-limit areas (Eronen at al., 1991). As one moves further south, or to lower altitudes, the picture becomes more complicated, since other climate parameters come to play a more important role in the vital processes that limit the growth of pine (Guiot et al., 1982). In this study forest-limit pines were sampled at eight sites in the timberline forest stands in the region (Fig. 1). The northernmost stands are located at Karasjoki, Skallovaara and Peuravuono. Five stands are in the Enontekiö region.

The number of trees per site studied ranged from 5 to 35 . The longest series dated back 334 years, while most of the series spanned from 150 to 250 years. After standardization a mean ring-width chronology was produced for each site. The areal mean value curves in Figure 2 share similar and very homogeneous growth trends, but also distinct areal patterns may be distinguished. Hardly any other environmental factor except climate could have caused such uniformity.

We compared the ring-width series with weather records from two meteorological stations. The meteorological station at Karesuando, Sweden, had continuous records of mean monthly temperatures and precipitation sums available for calibration for the period 1901-1990. The weather station at Karasjok, Norway, provided an even longer record from 1881 to 1990 . The data of these two stations correlated highly with each other, which indicates the homogeneity of climatic phenomena in the spatially large region of northern Lapland.

\section{METHODS}

\section{Standardization}

Stardardization is a means for extracting and enhancing the climatic signal in the measured ring-width series. It removes variability in ring-width series that is not related to climate (Cook \& Briffa, 1989; Fritts \& Guiot, 1989). Standardization involves removing part of the 


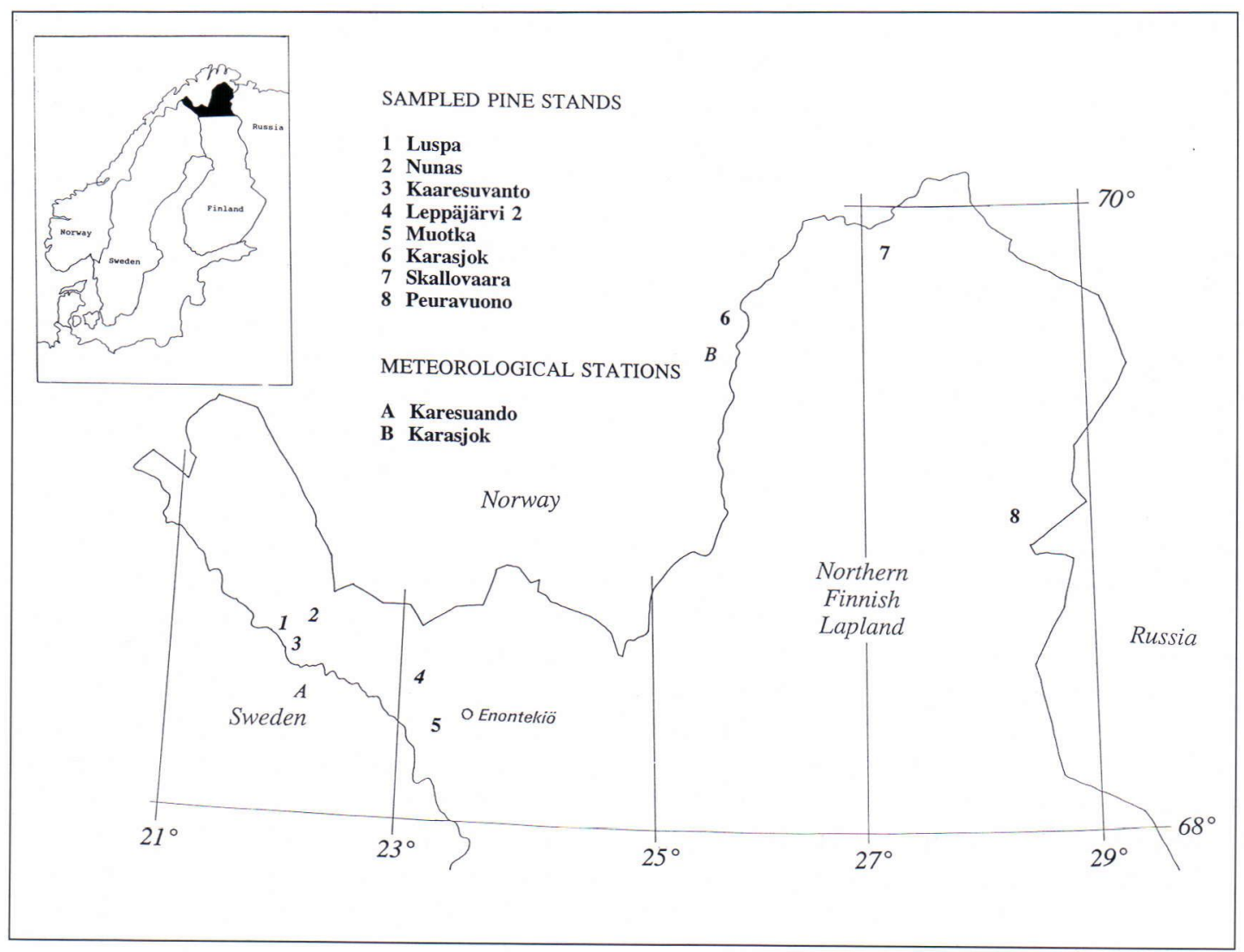

Fig. 1. Forest limit pines were sampled at eight sites in northern Lapland. Weather data was obtained from Karesuando and Karasjok.

low-frequency variability from the raw ring-width series. The rationale behind this is to remove trends in individual tree-ring series that arise as a consequence of non-climate-related growth processes such as ageing of trees and forest-stand development (Briffa et al., 1990).

To eliminate growth changes that are associated with increasing tree age, the raw tree-ring series were transformed to index-series. Raw measurements were divided by exponential curves fitted to these series (Graybill, 1982; Fritts, 1976). This also scales the mean of each series to about 1.0 and reduces the first order autocorrelation due to trend.

The ring-width index chronology for a given site is then obtained by averaging a number of such transformed indices together. The series of ring widths must be averaged to damp individual variations of growth and thus to gain a series showing the common response of a group of trees to climatic influences.

To produce a more homogeneous data set, with chronologies which are compatible in their lowand medium-frequency spectral character, we applied smoothing procedures to the data series. The $\mathrm{T} 4253 \mathrm{H}$ smoothing is described by Norusis (1993). Thus variability over 5 years will be emphasized.

\section{Calibration}

In dendroclimatological modeling the first step is to 

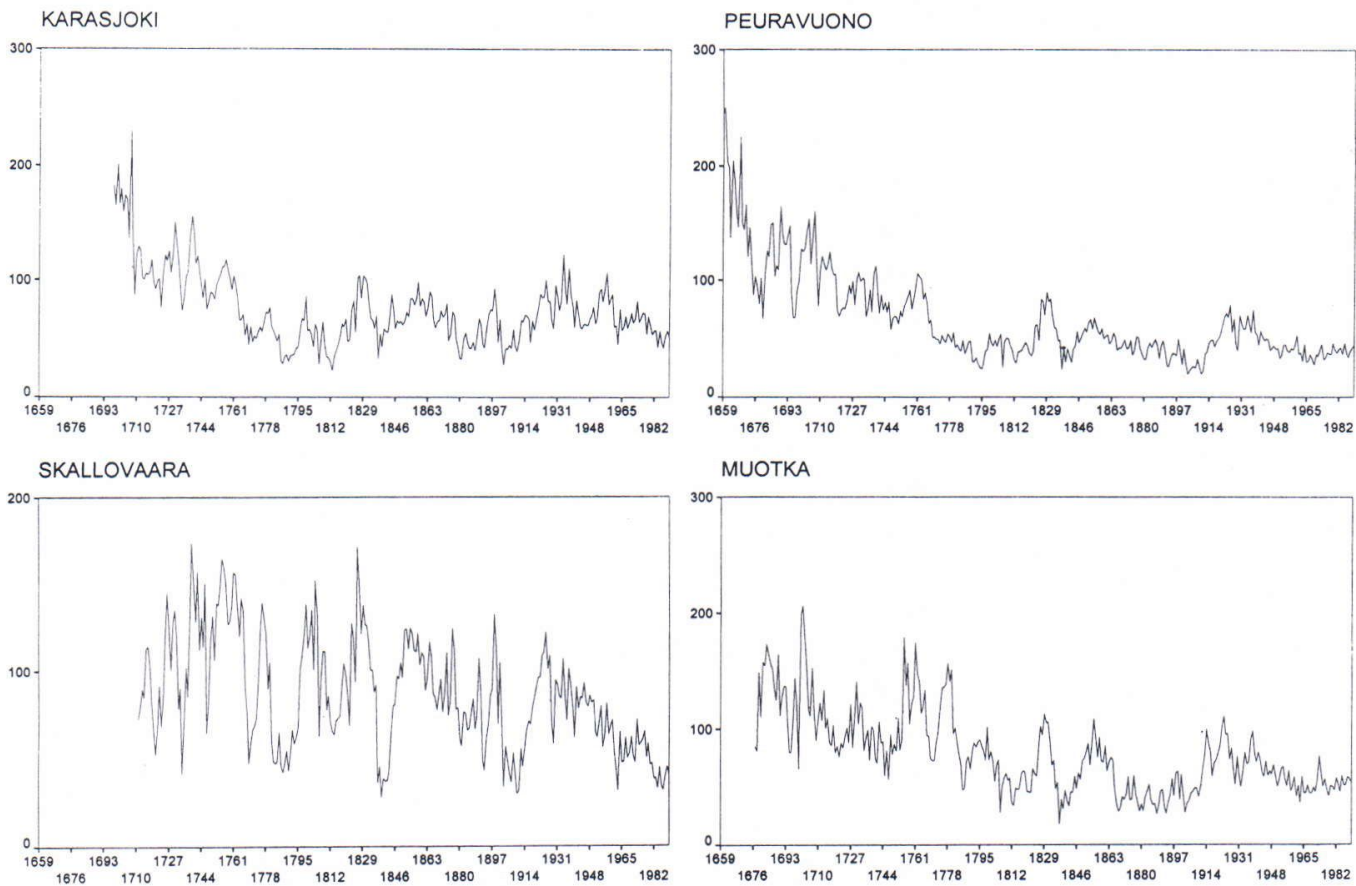

MUOTKA
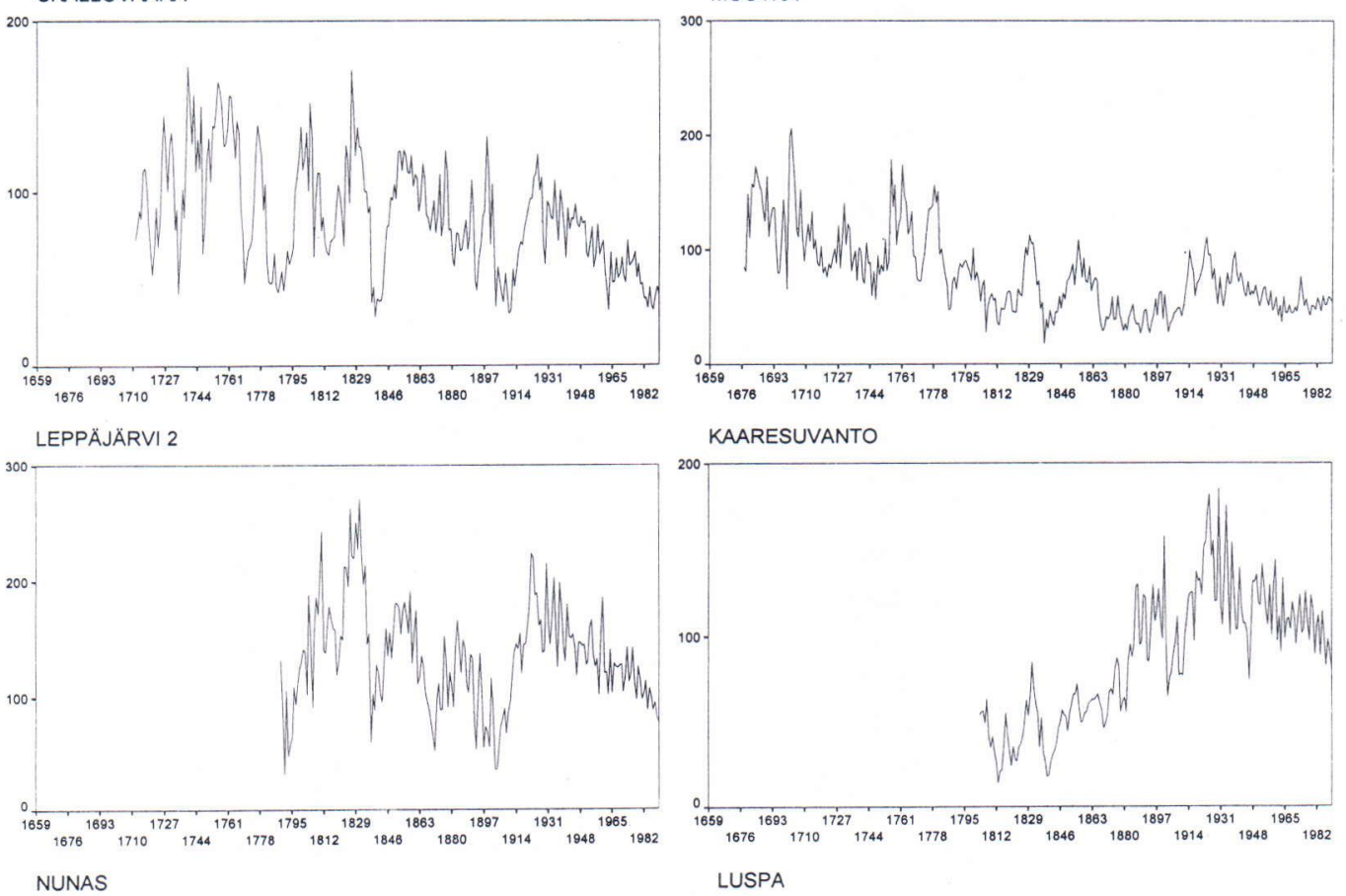

KAARESUVANTO
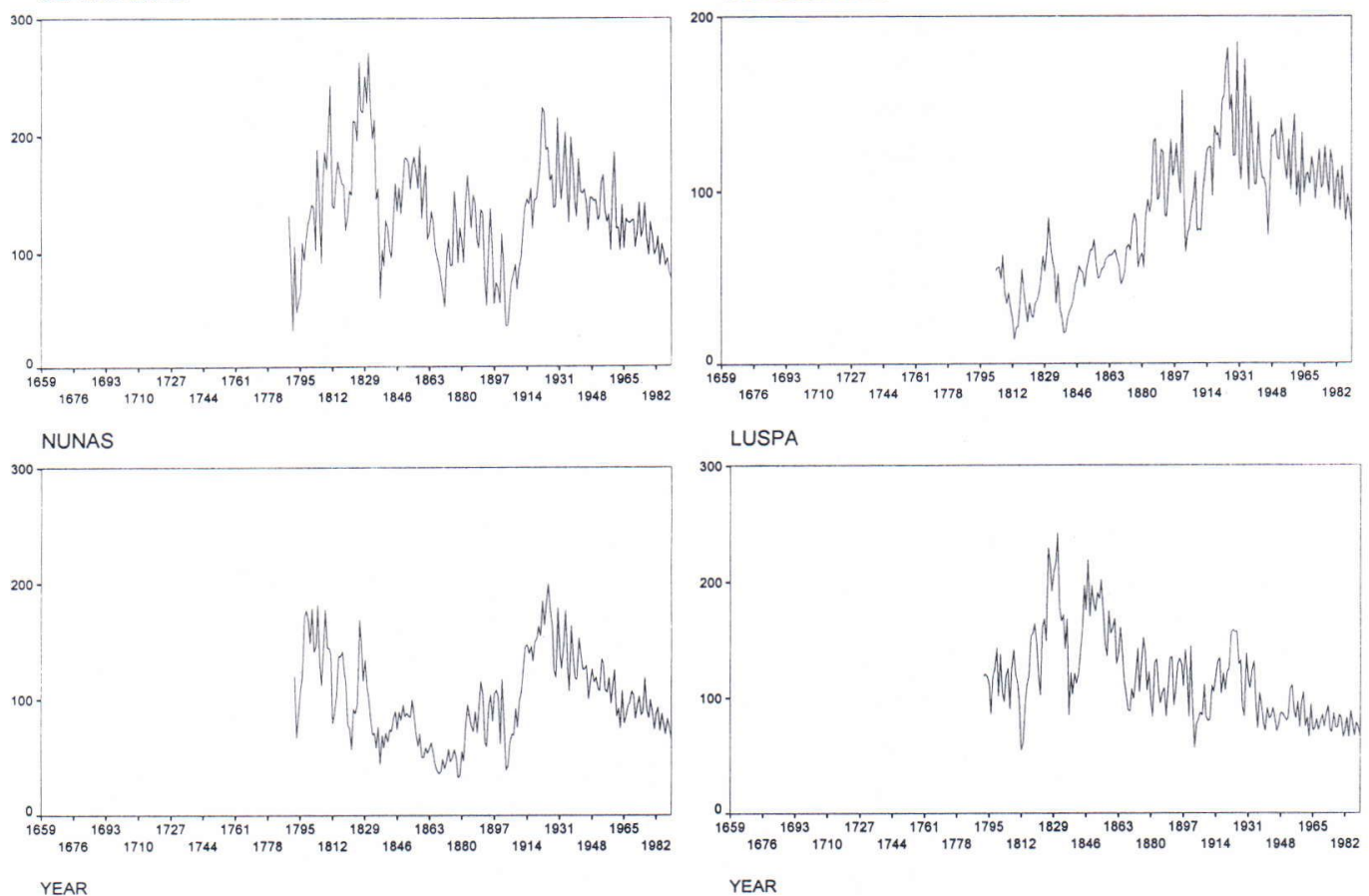

Fig. 2. Areal mean chronologies of Karasjoki, Peuravuono, Skallovaara, Muotka, Leppäjärvi 2, Kaaresuvanto, Nunas and Luspa. 
statistically quantify the relationship between ring-width variations and variations in climate (Fritts, 1976; Briffa et al., 1983; Briffa et al., 1986; Cook \& Briffa, 1989). This procedure fits principal components of the ring-width and climate data by means of linear multipple regression. Regression analysis may be applied in two ways, either to produce response models or transfer functions.

Response models are used to express the direction and relative strength of climatic forcing on tree growth, in order to define an optimum season for reconstruction. On the other hand transfer functions are used to calibrate the annual ring measurements with climate variables in order to produce regression equations for climate reconstructions. While the response function is a means of predicting tree performance from climate variables, climate reconstruction requires that climate variables be predicted from tree-ring variables (Fritts, 1982; 1989; Lofgren et al., 1982).

We have obtained statistically significant relationships between ring widths and climate and the respone functions used also show links which are biologically sensible. We estimated climate in year $t$ as a function of tree growth in years $t$ and $t+1$. Ring widths in previous years are included in the models, because ring-width time series are often strongly autocorrelated. The response function allows one to determine how much of the ring-width variance is determined by previous growth and by climate.

\section{RESULTS}

\section{Determining the parameters}

The strategy of dendroclimatology is to find a statistical relationship between biological output such as ring widths and a set of climatic variables such as temperature and precipitation. In nature precipitation and temperature are necessarily coupled for example through the processes which regulate evapotranspiration of a plant. In this study the effects of temperature and precipitation were first determined for the 14 months period from previous September to current October. A total of 28 climatic variables were taken to further analysis.

In addition to relative strength of climatic forcing on tree growth, two additional variables are taken into account, namely the ring width of the years $t-1$ and $t$-2. Fritts (1976) showed how the climate for a given year $t$ effects ring width not only for that same year $t$, but also in subsequent years so that the response reaches out up to several years. In this study we considered the effects of two previous years ring growth. Together with the climatic variables 30 predictors in all were on the same level in the response function analysis.

\section{The growth response of pines \\ to monthly precipitation sums}

Monthly precipitation data was regressed on tree growth indices of the eight study areas. In Figure 3 the three northernmost stands of Karasjoki, Skallovaara and Peuravuono (A) are compared with Karasjok station data and the stands in Enontekiö are compared with Karesuando station data (B). The lagging effect of two years previous growth is also illustrared (LAG 1 and LAG 2). A value above zero indicates a direct relationship and a value below zero indicates an inverse relationship.

Although several stands showed significant relationship with one or two precipitation variables at the 0.95 level, there were no evident pattern in growth response to precipitation at the different forest stands. Ring width of the years $t-1$ and $t-2$ were the most significant predictors in this analysis.

\section{The growth response of pines to mean monthly temperatures}

Figure 4 illustrates that temperature is of dominant importance for the growth at all sites. July temperature has by far the greatest influence, as experienced by the trees of the different forest stands. Again most of the variability is explained by the variable representing previous growth variable, namely LAG 1. 
A

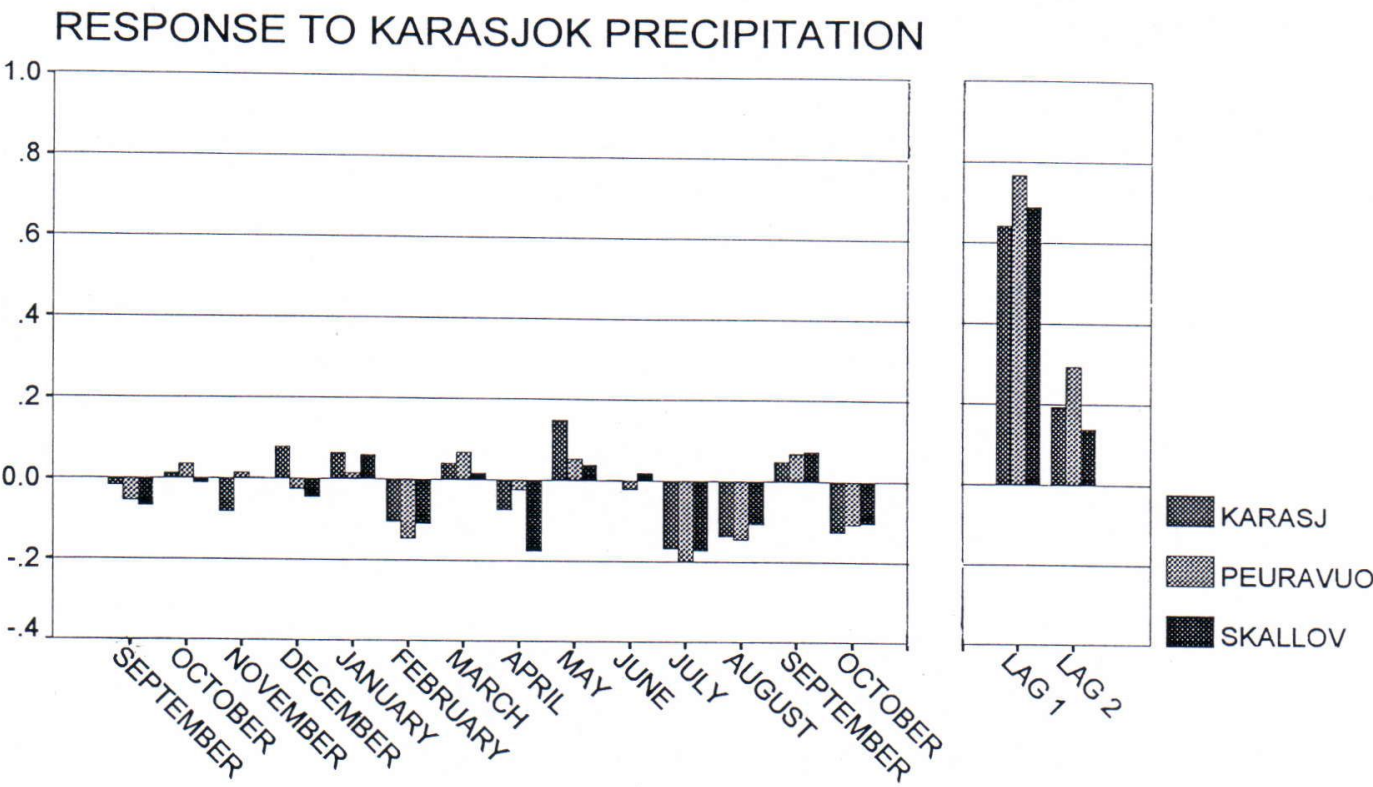

B

\section{RESPONSE TO KARESUANDO PRECIPITATION}

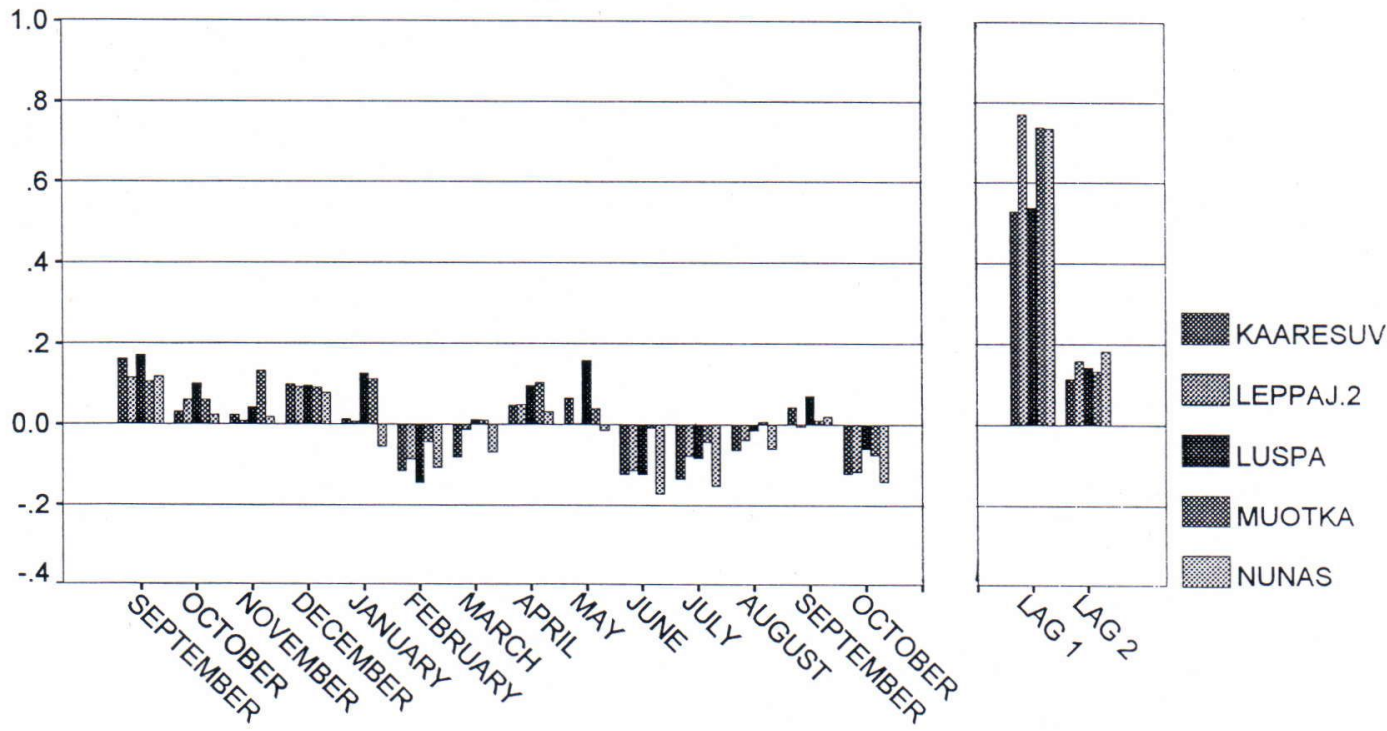

MONTH

Fig. 3. Patterns of growth response in Karasjoki (A) and Kaaresuvanto (B) pine to monthly precipitation. The predictors include 14 monthly sums of precipitation for successive months from September of the year preceding ring formation to October immediately following it. Ring width for two preceding years (LAG 1 and $L A G 2$ ) are also included. 
A

RESPONSE TO KARASJOK TEMPERATURES

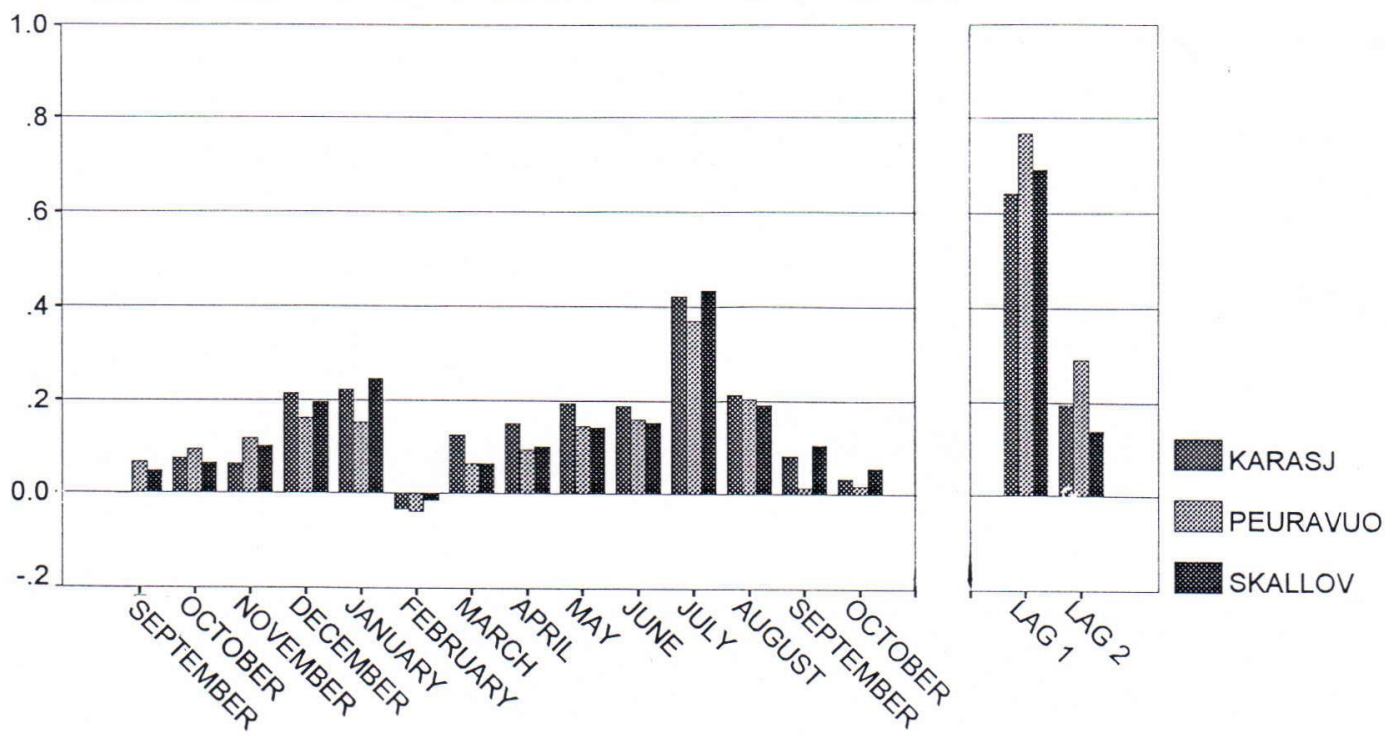

B

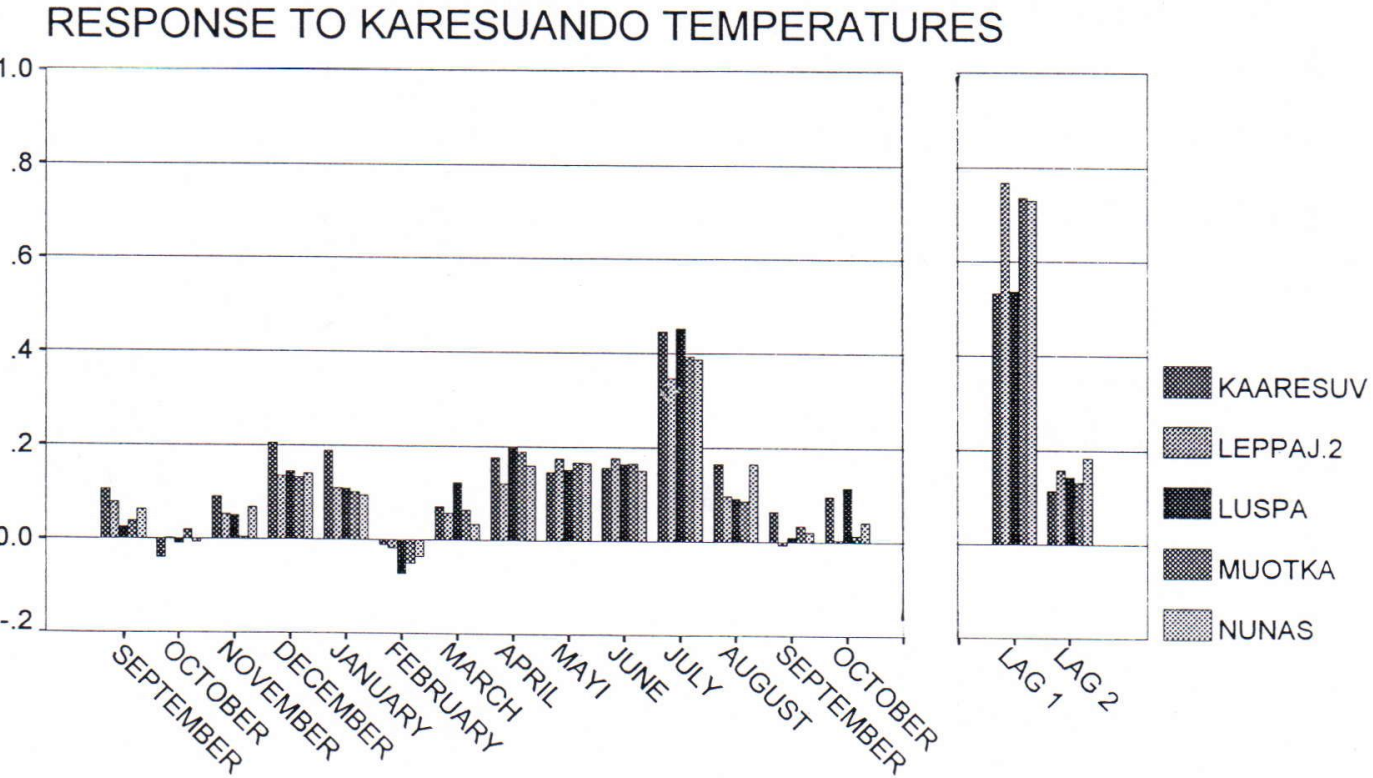

MONTH

Fig. 4. Patterns of growth response in Karasjoki $(A)$ and Kaaresuvanto $(B)$ pine to intra-annual temperature forcing. The predictors include 14 monthly temperature series for successive months from September of the year preceding ring formation to October immediately following it. Ring width for two preceding years (LAG 1 and $L A G$ 2) are also included. 
KAARESUVANTO

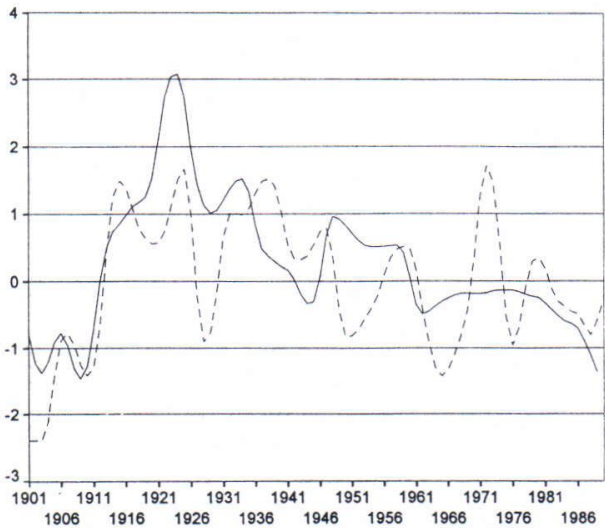

MUOTKA

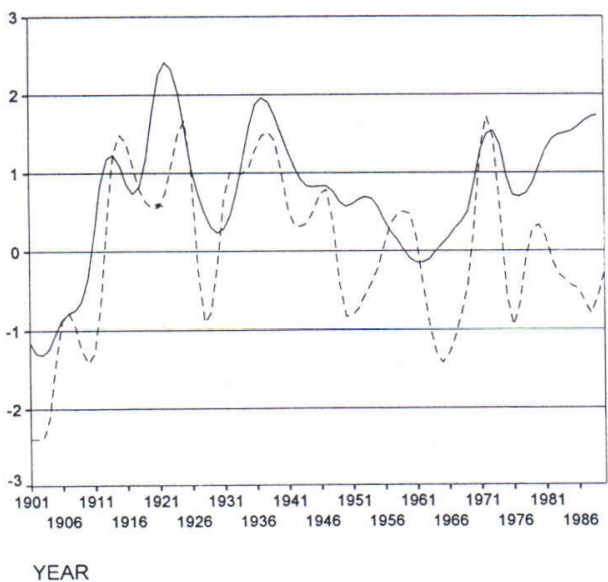

LEPPÄJÄRVI 2

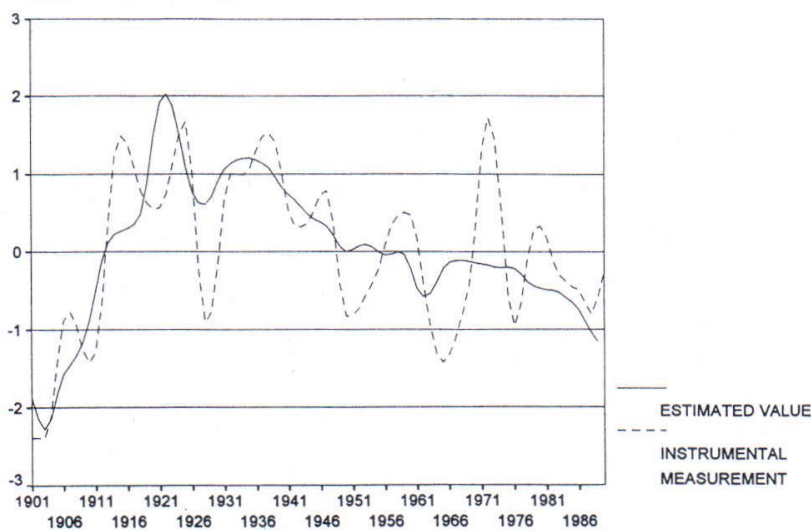

NUNAS

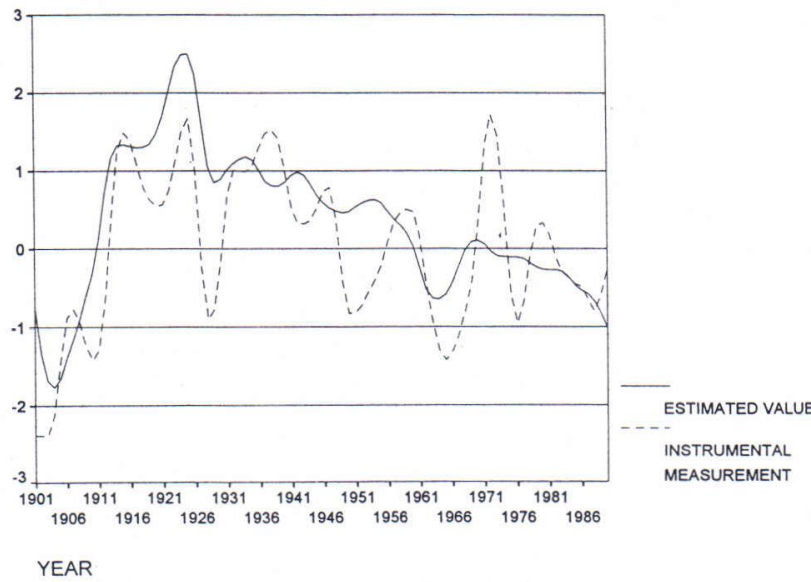

Fig. 5. The estimated versus observed values are plotted as departures from the mean. The reconstructed July temperature series at Kaaresuvanto, Leppäjärvi 2, Muotka and Nunas are plotted against measured values at the Karesuando meteorological station.

Four sites in the Enontekiö region, Kaaresuvanto, Leppäjärvi 2, Muotka and Nunas were selected for reconstruction and verification. From the northernmost stands Karasjoki and Peuravuono were also selected for further analyses.

\section{Verification}

For verification we compared the reconstructed values of July temperatures with the instrumentally measured data at two meteorological stations. In Figure 5 the estimated temperature series at Kaaresuvanto, Leppäjärvi 2, Muotka and Nunas are plotted against actually measured values at the Karesuando meteorological station. The estimated versus observed values are plotted as departures from the mean. During this period there is a good similarity between measured and reconstructed temperatures with correlation coefficients ranging from 0.66 to 0.74 .

Also the forest stands further north, Karasjoki 
KARASJOKI

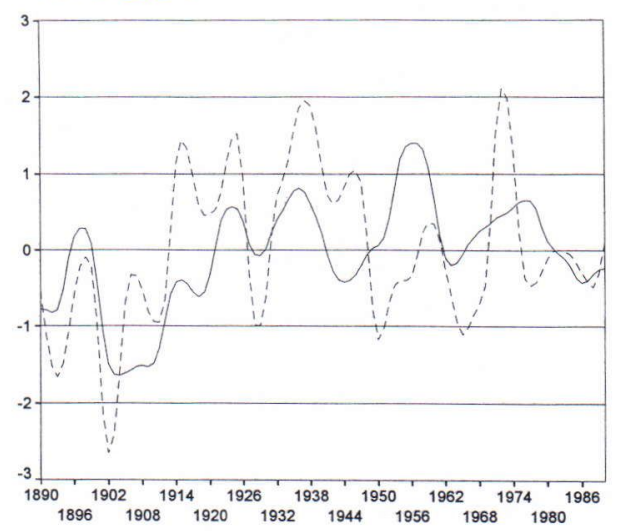

YEAR
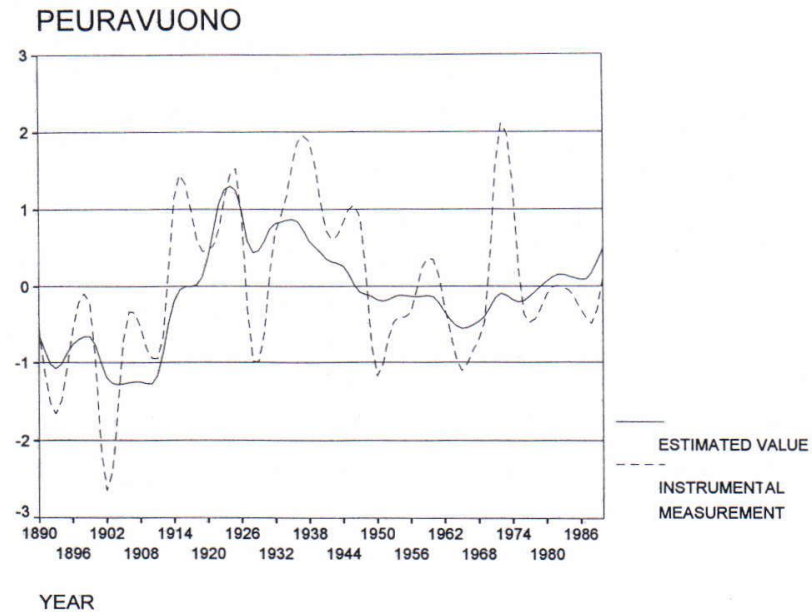

Fig. 6. The estimated and observed July temperatures at Karasjoki and Peuravuono. Values are departures from the mean.

and Peuravuono, yielded comparable similarities when compared with observational data from Karasjok weather station. Correlation coefficients were .55 and .68 correspondingly (Figure 6 ). On the basis of this climate-growth relationship we extended the six areal reconstructions as far back as the length of the tree-ring series made it possible.

\section{Areal reconstructions of summertime temperatures}

Because of the strong autocorrelation in tree-ring series the lag effect of previous years has to be considered (Fritts, 1976). We have used a transfer function (f) of the general form

$$
C_{t}=f\left(W_{t}, W_{t+1}\right)
$$

where $\mathrm{C}_{\mathrm{t}}$ is climate in year $\mathrm{t} . \mathrm{W}_{\mathrm{t}}$ and $\mathrm{W}_{t+1}$ are the tree-ring variables at various sites in years $\mathrm{t}$ and $\mathrm{t}+1$ (Cook \& Briffa, 1989; Briffa et al., 1983; 1988).

The four areal reconstructions of average July temperature in the Enontekiö region are presented in Figure 7. Estimated values are in normalized units, which are approximately equal to centigrade degrees. Reconstructions at Karasjoki and Peuravuono are presented in Figure 8.

Similarity of the reconstructions are revealed by some pointer years, which are evident in all our reconstructions. These years are known from the historical records as "years without a summer". A pointer year like 1816 shows up as a cool summer, but not unusually so. Years 1862 and 1867 are also known to be years of famine. Also the extremely unfavourable summers at the beginning of this century are clearly evident.

\section{DISCUSSION}

Our reconstruction seems to underestimate the extremes, especially the warmest summers. Reconstructions also tend to integrate previous effects for several years. This so-called persistence is well known property of tree-rings.

It is apparent in our reconstruction that several 
KAARESUVANTO

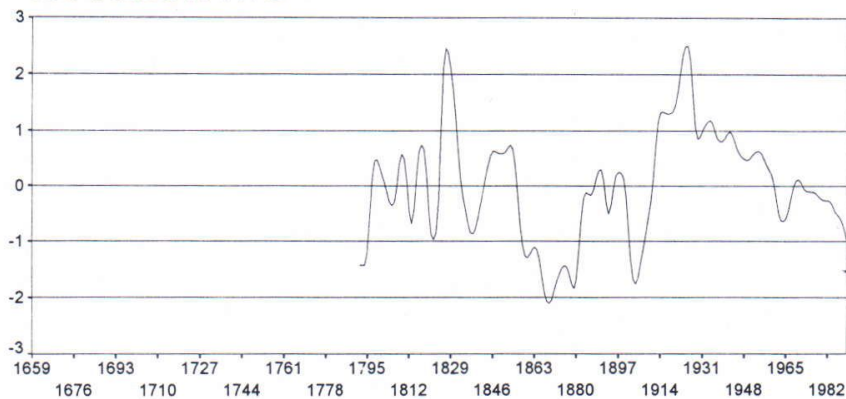

LEPPÄJÄRVI 2

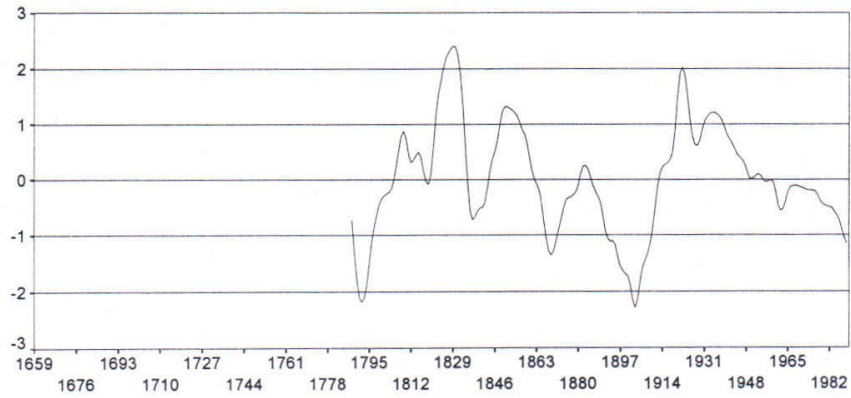

MUOTKA

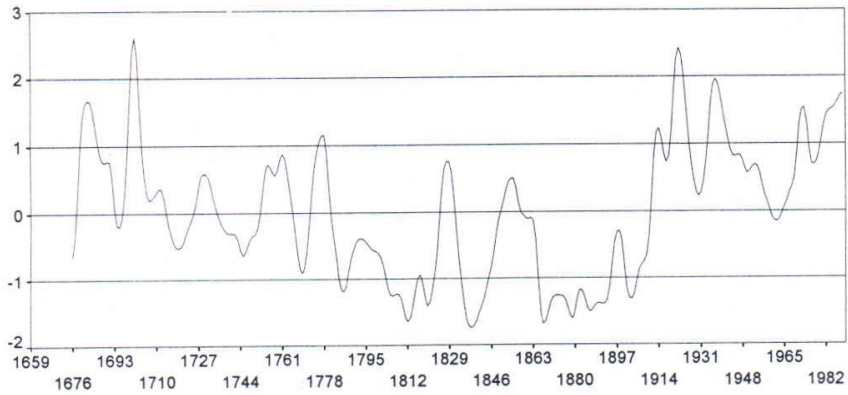

NUNAS

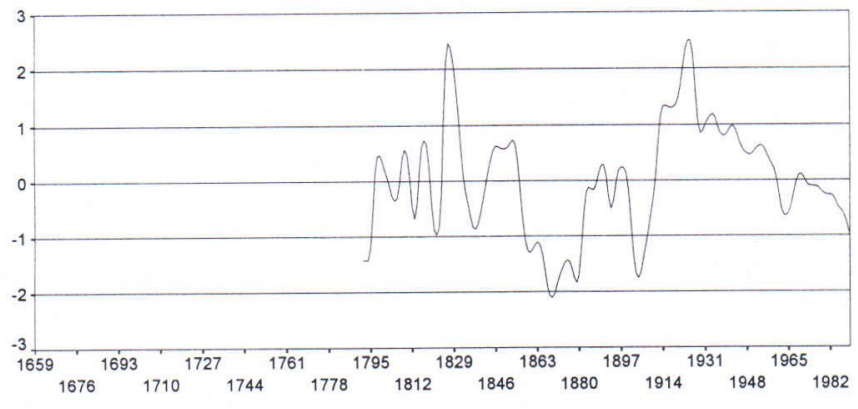

YEAR

Fig. 7. Reconstructed July temperatures at the four subareas in the

Enontekiö region. Normalized units are roughly equal to Celcius degrees. 
KARASJOKI

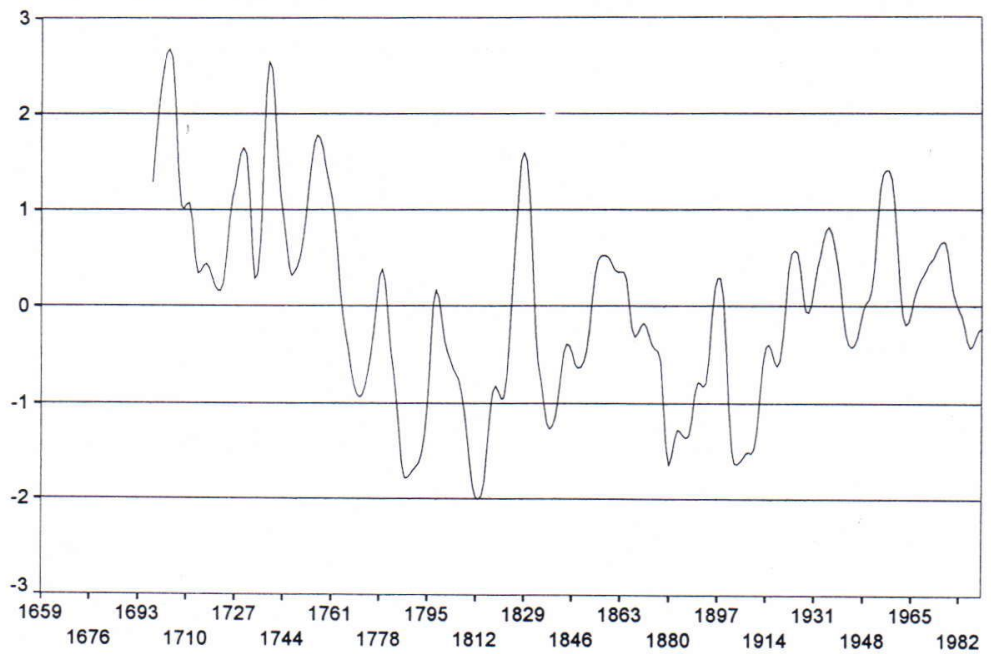

PEURAVUONO

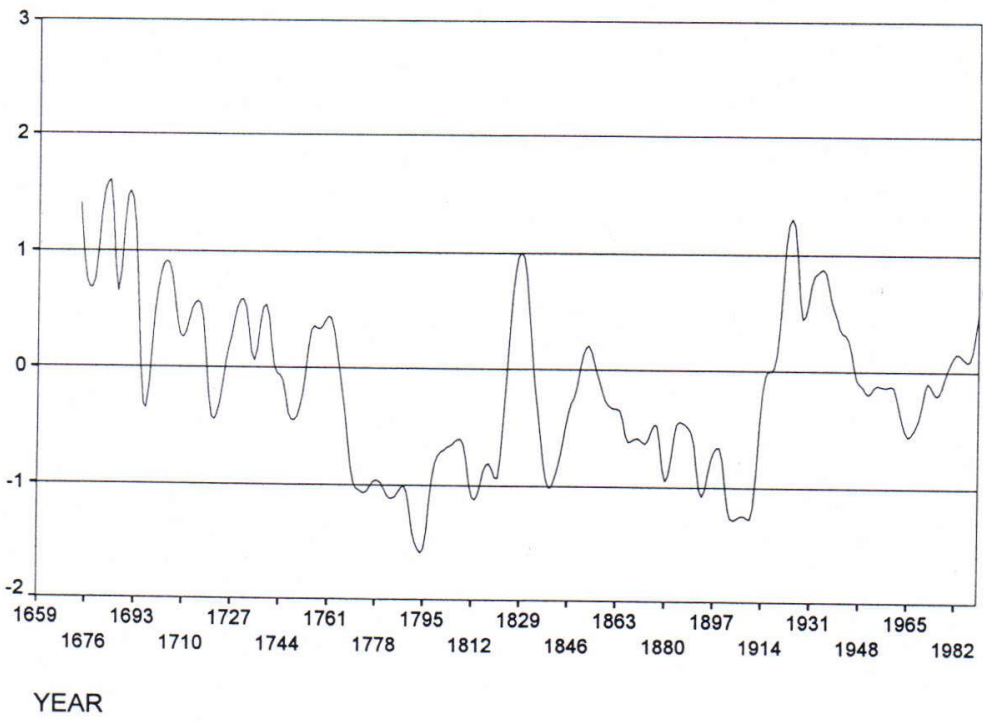

Fig. 8. Reconstructed mean July temperatures for Karasjoki and Peuravuono.

periods in the past have been equal in degree and duration to the relative warmth in the $1920 \mathrm{~s}, 1930 \mathrm{~s}$ and 19450s. They include 1750s, 1830s and 1840s. Other shorter warm periods are centered around years 1780, 1800, and 1880. Cool periods have prevailed in the 1760s, 1785-1795 and 1800-1825. The middle years of the coldest periods have been
1770, 1788, 1810, 1830 and 1867. Earlier reconstructions of summer temperatures in northern Fennoscandia show similar trends. These reconstructions have been made at the northern timber-line in Sweden (Aniol \& Eckstein, 1984) and over large areas covering parts of Norway and the Kola Peninsula (Briffa et al., 1988). 


\section{REFERENCES}

Aniol, R. \& Eckstein, D., 1984. Dendroclimatological studies at the northern timberline. In: Mörner, N.-A $\&$ Karlen. W. (eds.): Climatic changes on a yearly to millennial basis. D. Reidel Publ. Comp., 273-279.

Briffa, K.R., Jones, P.D. \& Wigley, T.M., 1983. Climate reconstruction from tree rings: Part 1. Basic methodology and preliminary results for England. Journal of Climatology 3, 233-242.

Briffa, K., Jones, P., Wigley, T., Pilcher, J. \& Baillie, M., 1986. Climatic reconstruction from tree rings: Part 2. Spatial reconstruction of summer mean sea-level pressure patterns over Great Britain. Journal of Climatology 6, 1- 15 .

Briffa, K., Jones, P., Pilcher, J. \& Hughes, M., 1988. Reconstructing summer temperatures in northern Fennoscandia back to A.D. 1700 using tree-ring data from Scots pine. Arctic and Alpine Research 20, 385-394.

Briffa, K., Bartholin, T., Eckstein, D., Jones, P., Karlen W., Schweingruber, F. \& Zetterberg P., 1990. A 1400-year tree-ring record of summer temperatures in Fennoscandia. Nature 346, 434-439.

Briffa, K., Jones, P., Bartholin, T., Eckstein, D., Schweingruber, F., Karlen, W. \& Zetterberg P., 1992. Fennoscandian summers from AD 500: temperature changes on short and long timescales. Climate Dynamics 7, 111-119.

Cook, E. \& Kairiukstis, L., 1989. Methods of dendrochronology: applications in the environmental science. Kluwer Academic Publishers, Dordrecht, 341 p.

Cook, E. \& Briffa, K., 1989. Data Analysis. In: Cook, E. $\&$ Kairiukstis,L.(eds.): Methods of dendrochronology: applications in the environmental science. Kluwer Academic Publishers, Dordrecht, 97-162.

Eronen, M., Huttunen, P. \& Zetterberg, P., 1991. Opportunities for dendroclimatological research in
Fennoscandia. Paläoklimaforschung - Palaeoclimate Research 6, 81-92.

Fritts, H.C., 1976. Tree Rings and Climate. Academic Press, London, $567 \mathrm{p}$.

Fritts, H.C., 1982. An overview of dendroclimatic techniques, procedures, and prospects. In: Hughes, M.K., Kelly, P.M., Pilcher, J.R. \& LaMarche Jr, V.C. (eds): Climate from tree rings. Cambridge University Press, Cambridge, 191-198.

Fritts, H.C., 1989. Statistical reconstruction of spatial variations in climate. In: Cook, E. \& Kairiukstis, L. (eds.): Methods of dendrochronology: applications in the environmental science. Kluwer Academic Publishers, Dordrecht, 193-210.

Fritts, H.C. \& Guiot, J., 1989. Methods of calibration, verification, and reconstruction. In: Cook, E. \& Kairiukstis, L. (eds.): Methods of dendrochronology: applications in the environmental science. Kluwer Academic Publishers, Dordrecht, 163-217.

Graybill, D.A., 1982. Chronology development and analysis. In: Hughes, M.K., Kelly, P.M., Pilcher, J.R. \& LaMarche Jr, V.C. (eds): Climate from tree rings. Cambridge University Press, Cambridge, 48-53.

Guiot, J., Berger, A.L. \& Munaut, A.V., 1982. An illustration of alternative transfer function methods in Switzerland. In: Hughes, M.K., Kelly, P.M., Pilcher, J.R. \& LaMarche Jr, V.C. (eds): Climate from tree rings. Cambridge University Press, Cambridge, 160-162.

Hughes, M.K., Kelly, P.M., Pilcher, J.R. \& LaMarche $J r, V . C ., 1982$. Climate from tree rings. Cambridge University Press, Cambridge, $223 \mathrm{p}$.

Lofgren, G.R., Hunt, J.H. \& Gray, G.M., 1982. Transfer functions. In: Hughes, M.K., Kelly, P.M., Pilcher, J.R. \& LaMarche Jr, V.C. (eds): Climate from tree rings. Cambridge University Press, Cambridge, 50-57.

Norusis, M.J., 1993. SPSS, Base System User's Guide, Release 6.0. SPSS Inc., Chicago, 828 p. 